\title{
Why Do Financial Inclusion Policies Fail in Mobilizing Savings from the Poor? Lessons from Rural South India *
}

Jann Goedecke ${ }^{1,2 \dagger}$, Isabelle Guérin ${ }^{3,4}$, Bert D’Espallier ${ }^{1}$ and Govidan Venkatasubramanian ${ }^{4}$

\section{Note that this is the open-access version of the paper. This paper is forthcoming in Development Policy Review}

\author{
${ }^{1}$ KU Leuven, Brussels, Belgium \\ ${ }^{2}$ Universitetet i Agder, Kristiansand, Norway \\ ${ }^{3}$ Institute of Research for Development (IRD), Paris, France \\ ${ }^{4}$ French Institute of Pondicherry, Pondicherry, India
}

\footnotetext{
*Acknowledgements: This article is based on data collected between 2008 and 2012 with the French Institute of Pondicherry and within the research project 'Rural Microfinance and Employment (RUME): Do Processes Matter?', funded by the French National Agency for Research (ANR). We would like to thank Prabesh Luitel, Ziaoul Haque Munim, and the anonymous reviewers for their constructive comments and suggestions. We are also grateful to the participants of the $4^{\text {th }}$ European Research Conference on Microfinance held in Geneva, Switzerland, in June 2015 for helpful feedback.

$\dagger$ Corresponding author: jann.goedecke@ kuleuven.be, tel: +32 260988 59, address: KU Leuven, Campus Brussel, Research Group Finance, Accountancy and Tax, Warmoesberg 26, 1000 Brussel, Belgium; University of Agder, School of Business and Law, Gimlemoen 25, 4630 Kristiansand, Norway
} 


\begin{abstract}
Combining multivariate and qualitative analyses, this micro-level study suggests an explanation for the persistence of informal savings in rural South India despite publicly run large-scale programs to promote bank savings. Notably gold, but also ROSCAs and private lending, remain dominant forms of saving. We argue that cultural norms and social institutions such as social class and caste shape the nature, the propensity but also the opportunities to save. Gold serves multiple purposes, which are financial, economical, socio-cultural, and political. Furthermore, we find that Dalits' (the lowest caste) preference for gold illustrates a relative emancipation of Dalits combined with the maintenance of prohibition related to caste which prevents them to invest in other assets such as land.
\end{abstract}

Key words: informal saving, financial inclusion, banks, microfinance, India, political economy, economic anthropology

JEL-classification codes: O17, O53, Z13 


\section{Introduction}

Saving is often considered the forgotten half of microfinance. Though the idea is not new (Vogel, 1981), helping the poor to save more is receiving increased attention (Karlan et al., 2014). In the absence of a public health system and social security, as in many developing countries, it may help them to cope with risks and emergencies (Morduch and Sharma, 2002). It can also help them to better plan for their future, whether for life cycle and ritual events, education, housing or economic investments (Collins et al., 2009). Contrary to microcredit, it cannot push people into vicious circles of over-indebtedness (Guérin, Morvant-Roux and Villarreal, 2013: 301-2). In a recent review, Karlan et al. (2014) suggest that a lot remains to be done to better understand the disappointing results in terms of savings mobilization. In this paper, and drawing on an Indian case, we argue that the social and cultural dimensions of savings have been underestimated, and this may explain disappointing savings results.

According to recent data from the Global Financial Inclusion database (Global Findex), worldwide, $57 \%$ of adults report having saved money in the past 12 months, but only $27 \%$ have done so in a formal institution (Demirgüç-Kunt et al., 2015). For India, figures amount to 38\% of individuals reporting current accumulation of savings, but only $14 \%$ had savings in a formal institution. In 2006, a first 'financial inclusion program' was launched by the Reserve Bank of India (RBI), whose main objective was to provide a bank account for all households with a fixed address, with a particular focus on rural areas. 'Bancarisation' was supposed to develop 
'a culture of saving among large segment of rural population' (RBI, 2013: 3 ). ${ }^{1}$ Although these policies have boosted bank account provision in India considerably from 35\% in 2011 up to 53\% in 2014, usage remains extremely low, around 4\% (Demirgüç-Kunt et al., 2015).

Previous studies in different local contexts, where subsidized or free saving bank accounts were offered to the unbanked in a randomized way, have similarly found a low usage rate of bank accounts. In Kenya, $62 \%$ of low income households opened a savings account they were offered for free, whereas merely $18 \%$ used it to save (Dupas et al., 2012). A similar experiment in Kenya by the same authors showed a take up rate of $87 \%$, but only $41 \%$ household made at least one transaction within the first six months (Dupas and Robinson, 2013). In the Philippines, women were offered commitment savings products: only $28 \%$ took up the product, of which only around one third used it regularly, so that eventually only $10 \%$ of the sample population saved more (Ashraf et al., 2010).

In this study, drawing on a unique dataset from rural South India combined with a wide range of qualitative research methods including interview records, group discussions and participant observations, we show that informal saving types are still widespread and much more common devices to save than are bank accounts. The dominant forms of saving are gold, Rotating Saving and Credit Associations (ROSCAs), and lending to others. Though these various practices cannot in every instance be strictly qualified as saving, they are often considered and used as such by local populations. Informal savings, and gold in particular, serve multiple purposes, which are economical (the rate of gold has been constantly rising), socio-cultural (saving in

\footnotetext{
${ }^{1}$ The objectives are defined as follows: Financial inclusion broadens the resource base of the financial system by developing a culture of saving among large segment of rural population and plays its own role in the process of economic development. Further, by bringing low income groups within the perimeter of formal banking sector; financial inclusion protects their financial wealth and other resources in exigent circumstances. Financial inclusion also mitigates the exploitation of vulnerable sections by the usurious money lenders by facilitating easy access to formal credit (see RBI, 2013).
} 
gold is a matter of identity and used as a major component of marriages and brides' dowry), and political (loans manifest hierarchical relations). In particular we observe that, all things being equal, Dalits, who represent the lowest caste, show a higher propensity to save in gold. This illustrates broader socio-economic, cultural and political trends, namely the Dalits' relative emancipation from dependency upon higher castes, combined with increasing incomes. However, discrimination is still persistent, and Dalits are inhibited to purchase land or lend money to higher caste members. Our study has important policy implications as it highlights factors that help explain the failure of 'financial inclusion' policies that assume an automatic shift from informal to formal savings, once they become available.

In the remainder of the article, Section 2 presents a theoretical framework of the different concepts around savings behaviour and synthesizes the relevant literature. Section 3 describes the methodology of the study and puts it into the local context. Section 4 presents evidence, combining qualitative and quantitative analyses, for the persistence and significance of informal saving types, and how social regulations affect the choice and opportunity to save. Finally, Section 5 discusses the results in light of policies aiming at financial inclusion in India and concludes.

\section{Theoretical framework}

\subsection{Existing paradigms to explain savings behaviour}

In economic theory, a distinction is often made between precautionary saving i.e. to smooth consumption or cope with negative income shocks, and investment saving i.e. to maximize expected future consumption. Deaton (1990) developed a microeconomic model explaining savings behaviour particularly in developing countries, according to which the primary 
function of savings is to buffer consumption in the short to medium term. More recently, insights from psychology and behavioural economics emphasize the individual component in saving, linking the low propensity to save among the poor to cognitive and psychological resistances (Banerjee and Duflo, 2011; Karlan et al. 2014). These include for instance lack of self-control, cognitive dissonance, or loss aversion. Better marketing, adapted to people's psychological features, would then allow to overcome people's natural reluctance to save (Atkinson et al., 2012). Another key explanatory factor for under-saving is 'social pressure' in the sense that people are often urged to support their close circle, effectively acting as a 'tax' on household savings (Platteau, 2000; Karlan et al., 2014).

Other features that determine the extent to which households are able to save are reliability (Bouman, 1989; Collins et al., 2009), discretion and anonymity (Vonderlack and Schreiner, 2001), self-discipline and structure (Collins et al., 2009; Vonderlack and Schreiner, 2001). They also underline the blur distinction between saving and borrowing from the household perspective (Rutherford, 2001; Morvant-Roux, 2013).

Though these approaches certainly help for a better understanding of savings behaviour at the micro level (Labie et al., 2015), we believe they miss part of the explanation as they ignore the social, cultural and political dimensions of saving. Several weaknesses can be noted. First, these approaches fail to understand the diversity of savings behaviour across regions and individuals tied to their social and cultural background. However, to understand people's motivation to save in a certain way, we need to consider the social, cultural and political roles of different kinds of savings (Servet, 1995). Second, most neglect the persistence of informal savings. Informal savings are systematically considered as risky and sub-optimal. For instance, Banerjee and Duflo (2011: 188) state that informal saving practices are 'complicated' and 'costly' and argue that banking services would be much better (see also for instance Karlan et al., 2014; Dupas et al., 2012; Rosenzweig, 2001). Yet, understanding why bank accounts 
remain largely underused and informal savings persist, requires to consider people's constraints and rationales - which go beyond behavioural constraints. Third, these approaches ignore the long term concerns of the poor. Following Rosenzweig (2001), most studies consider that the poor are, in essence, unable to have long term considerations since survival in the short term is their primary concern. Precautionary saving to smooth income would therefore be the most common form of saving, while investment saving would be inexistent.

Similar to behavioural approaches, much of the effort spent on implementing financial inclusion policies is based on the assumption that costs of banking services are the main force behind financial exclusion. In India, financial inclusion policies follow a supply side-centred approach (RBI, 2013) and try to achieve financial inclusion by providing access to basic banking services such as a 'no-frills' saving account. This implicitly reflects the idea that by giving low-cost access to banks, people can be 'nudged' to integrate themselves into the financial system. Yet, it might be a long road from access to usage of bank accounts. Thus, in some instances where banks reported $100 \%$ bank account coverage among some Indian districts (Cnaan et al., 2011), successes in achieving financial inclusion might have been declared prematurely. One feature in the concept of financial inclusion is that it is 'geared to the individual household level and does not imply peer relationships' (Cnaan et al., 2011: 185). We argue that financial inclusion policies may thus fail to recognize that financial arrangements within households do not occur in a social and cultural void (Salignac et al., 2016), but in contrast are highly interconnected between households' social relationships and dependent on their cultural context.

\subsection{An interdisciplinary approach to understand the complexity of saving behaviours}

The paper draws on the insights of sociology, political economy and economic anthropology, which allows for a better understanding of the complexity of saving behaviours. We analyse to 
what extent caste and class determine the access to and use of various saving types. Hoarding money may in one context be held as a sign of wisdom and responsibility, while in another it may be associated with greediness, cupidity and egocentrism (Douglas and Isherwood, 1980: 13; Guyer, 1997). Opportunities and desire for upward mobility foster and legitimate saving behaviours, as observed in many migrant communities but also in marginalized groups aspiring to social change. Conversely, in contexts in which community bonds play a key role of protection (which is still the case in many places where institutionalized protection is lacking), people are embedded into a wide range of ties which are both social and financial: money must change hands quickly and hoarding goes directly against this common rationale (Guérin et al., 2011). The same rationale explains why people tend to rank saving possibilities not only in terms of security but also in terms of social considerations: strengthening their belonging to the group is as important as financial gains (Servet, 1995; Morvant-Roux et al., 2014). Investing in 'social wealth' (cementing social relationships through giving or lending to others) is just as crucial as accumulating money, goods and assets (Guyer, 1997). Social stratification and institutions may also explain in great part why some communities perform better in terms of savings than others. For instance it is often the case that tax rules benefit particular groups while they serve others very poorly (Sherraden, 1991). Due to regulation and social norms, some groups are allowed to perform certain economic activities, which in turn facilitate saving and accumulation, while others are not. 


\section{Methodology}

\subsection{Research methodology and data collection}

This study complements multivariate analyses of household surveys with qualitative analysis to understand how and why people save. The collection of both the qualitative and the quantitative data was part of the broader research program RUME (Rural Microfinance and Employment $^{2}$ ) launched in 2003 and running over ten years, centred around questions on labour and finance behaviour and situated in coastal/central Tamil Nadu (South India).

In a first step, qualitative data was collected through semi-structured interviews in the study area, in order to explore saving practices of the local population. One of the purposes was to analyse attitudes and strategies toward savings, taking into account the diversity of saving relationships, both from a financial perspective (such as degree of liquidity or duration) and from a subjective perspective. 25 interviews had a particular focus on saving, but a large number of semi-directive interviews (approximately 150) around topics such as debt, selfemployment or gender relations were also used to capture relevant information. Further information on savings was obtained through other methodological tools such as informal interviews, group discussions and participant observations. In addition, those methods helped to verify (or rectify) information given by the respondents in the semi-structured interviews. The combined initial analysis of the obtained data allowed us to identify several forms of financial transactions that were perceived as saving by the local communities.

Subsequently, drawing on the exploratory results, a structured questionnaire was developed. This step-wise procedure enabled us to collect detailed statistical data for various saving

\footnotetext{
${ }^{2}$ Details about the RUME project can be found at http://www.rume-rural-microfinance.org/
} 
practices, which had been considered relevant by the local communities. Additionally, it helped framing the survey questions in locally common terms and thus to avoid misunderstandings. In total 1,929 individuals from 405 households were surveyed in 2010, spread across ten villages in northern coastal rural Tamil Nadu on the border of the two districts Villupuram and Cuddalore. Households and villages were randomly selected, using a stratified sample based on caste and location in terms of water availability and distance to town. In this part of the analysis we sought to demonstrate how saving patterns are separated by social, cultural and economic characteristics.

Since the various saving practices used by households are likely to be interdependent, we applied a Seemingly Unrelated Regression (SUR) model (Zellner, 1962), which allows for correlation of the error terms across equations. In addition to the linear coefficient estimates, the SUR model yields an estimate for the correlation matrix of the residuals, which enabled us to investigate how saving practices were quantitatively related with each other, and to detect potential substitution effects, for instance between informal and formal savings. We applied the SUR methodology to both continuous dependent variables and to dichotomous dependent variables (the latter also being known as Bivariate Probit model; see Zellner and Lee, 1965). The results from the regressions were then put into context by turning again to qualitative analysis of the interview records. This helped to better understand the processes underlying the identified correlations (Rao and Woolcock, 2003).

\subsection{Context of study}

The studied zone is economically dynamic featuring a large proportion of irrigated agriculture, two industrial towns (Neyveli and Cuddalore) and a regional business centre (Panruti). As elsewhere in Tamil Nadu and India, caste remains a fundamental factor in social, economic, ritualistic and political life. Caste here is inherited through one's birth group. It is characterized 
by endogamy, the rules of commensality and hierarchy, the latter still being associated with ritual dirt and pollution. Vanniyars and Paraiyars are the two major local groups across the region. Vanniyars are a farming caste with a low ritual rank, but in the villages we studied, as in many places in northeast Tamil Nadu, they control much of the land and are politically dominant. ${ }^{3}$ Paraiyars are one of the three major Dalit (ex-untouchable) communities in Tamil Nadu. They are particularly well-established in the north of the state. There are also few Arunthathiyars among the Dalits. The upper castes of the local hierarchy are the Mudaliyars, Naidus, Reddiyars and Settus, who account for only a small proportion of the village population. Christians and Muslims are a minority in the area.

The region has seen many changes over the last three decades. Upper castes have mostly moved away from the villages to nearby towns, adopting urban jobs and lifestyles, and selling an important part of their land to Vanniyars. Overall, upper castes still have a hold on village life but are not as powerful as they used to be. Land transfers to Vanniyars explain in great part why they are now dominant. As for Dalits, their situation has been improving, albeit unequally across villages, thanks to the combination of short term migration to nearby towns and industrial centres, and governmental schemes (reflected by subsidized housing, food, education, etc.; Guérin et al., 2014).

\footnotetext{
${ }^{3}$ There are also a few Gramanis, Navithars, Nattars, Kulalars and Asarais, who have a similar position in the caste hierarchy.
} 


\section{Results}

\subsection{Caste membership, land ownership and socio-economic characteristics}

Table 1 summarizes socio-economic characteristics of the 405 sample households. Dalits are over-represented among casual agricultural labourers with $57 \%$, compared to $40 \%$ in the middle and only $10 \%$ in the upper caste. In contrast, only $7 \%$ of the Dalits are farmers, while the numbers amount to $23 \%$ for the middle caste and $18 \%$ for the upper caste. Household occupation was given by the main breadwinner's activity, and in case he/she had several occupations, we considered the one that was reported to contribute most to the household income. Self-reported annual income is lowest for the Dalits (roughly 34,000 INR ${ }^{4}$ ) compared to middle (34,600 INR) and upper caste members (45,700 INR). Differences between castes in asset ownership are more pronounced and the disadvantage of Dalits becomes more apparent here (Dalits: 840,000 INR, middle castes: $1,750,000$ INR, upper castes: $2,000,000$ INR).$^{5}$ In part, Dalit households compensate for their lower average income through a somewhat lower dependency ratio, defined as the share of members in a household not having any income, including children and elderly. Further, they display a significantly higher share of female labour (on average $70 \%$ of working age women in Dalit households have an income, compared to $59 \%$ and $44 \%$ in middle and upper castes, respectively). Social status according to the caste is reflected in land ownership: The lowest figure, $42 \%$, is found for Dalits (middle castes $71 \%$, upper castes 52\%), and among all land owners, Dalits' have the smallest plots (on average 1.43

\footnotetext{
${ }^{4}$ At the time of the survey, the market exchange rate was approximately 45 Indian Rupee (INR) per US Dollar. ${ }^{5}$ Since upper caste households are economically more involved in urban areas, they may report their assets more inaccurate than purely rural dwellers. For instance, they may own real estate in nearby cities which is sometimes registered on their sons' names to make use of tax benefits. However, all subsequent analyses were also performed excluding upper caste members, which in no case changed the results qualitatively.
} 
acres, middle castes 2.23, upper castes 3.11) and their land titles are of significantly less value $(\mathrm{p}<0.1 \%)$. This coincides with the high share of, typically landless, casual labourers among the Dalit caste.

Land holdings in India do not only constitute an investment asset, but are also attached to local political power and reinforce hierarchical relations (Levien, 2015). In our study area, Dalits virtually had no access to land holdings leased out by higher castes, which is manifested by pure social norms (Iversen et al., 2014). Historically, upper castes were the main landowners. Still continuing today, many have been selling a large part of their land as they shift to urbanbased activities, but most refuse to sell to Dalits. By analogy, it is also very difficult for Dalits who own land to lease it out to higher castes.

Table 1: Socio-economic characteristics of the sample (average values by caste)

\begin{tabular}{|c|c|c|c|c|c|c|}
\hline \multirow[b]{2}{*}{ Household characteristics } & \multirow[t]{2}{*}{ Dalits } & \multirow[t]{2}{*}{ Middle } & \multirow[t]{2}{*}{ Upper } & \multirow[t]{2}{*}{$\begin{array}{r}\text { Total } \\
\text { sample } \\
\end{array}$} & \multicolumn{2}{|c|}{$\begin{array}{l}\text { Test stat: Dalits vs } \\
\text { other castes a }\end{array}$} \\
\hline & & & & & & \\
\hline$\overline{\text { Household size }}$ & 4.9 & 4.7 & 4.6 & 4.8 & -1.569 & \\
\hline Age of head of household & 46.7 & 48.1 & 51.2 & 47.9 & 2.396 & * \\
\hline \multicolumn{7}{|l|}{ Education level of head of household: } \\
\hline No Education & $55 \%$ & $43 \%$ & $34 \%$ & $47 \%$ & 10.558 & $* *$ \\
\hline Primary & $19 \%$ & $19 \%$ & $21 \%$ & $19 \%$ & & \\
\hline Secondary or above & $26 \%$ & $38 \%$ & $45 \%$ & $33 \%$ & & \\
\hline \# boys in household & 1.43 & 1.21 & 1.21 & 1.31 & -2.761 & $* *$ \\
\hline \# unmarried girls age 14+ & 0.48 & 0.45 & 0.46 & 0.46 & -0.403 & \\
\hline \# daughters-in-law in household & 0.18 & 0.23 & 0.24 & 0.21 & 1.298 & \\
\hline \multicolumn{7}{|l|}{$\underline{\text { Economic indicators }}$} \\
\hline Total assets (in INR) & 839,613 & $1,749,058$ & $2,001,291$ & $1,360,928$ & 6.191 & $* * *$ \\
\hline Average working members income & 33,973 & 34,597 & 45,669 & 36,133 & 1.406 & \\
\hline Women: share working & 0.70 & 0.59 & 0.44 & 0.62 & -4.332 & $* * *$ \\
\hline Dependency ratio & 0.46 & 0.47 & 0.49 & 0.47 & 0.833 & \\
\hline \multicolumn{7}{|l|}{ Main occupation: } \\
\hline Farmer & $7 \%$ & $23 \%$ & $18 \%$ & $15 \%$ & 35.741 & $* * *$ \\
\hline Casual labour & $57 \%$ & $40 \%$ & $10 \%$ & $43 \%$ & & \\
\hline Employed & $23 \%$ & $23 \%$ & $31 \%$ & $25 \%$ & & \\
\hline Self-employed & $12 \%$ & $13 \%$ & $40 \%$ & $17 \%$ & & \\
\hline \multicolumn{7}{|l|}{ Land ownership } \\
\hline Land ownership & $42 \%$ & $71 \%$ & $52 \%$ & $54 \%$ & 21.660 & $* * *$ \\
\hline Acres (only landowners) & 1.43 & 2.23 & 3.11 & 2.08 & 4.414 & $* * *$ \\
\hline Land value (only landowners, in INR) & $1,374,444$ & $2,002,577$ & $3,071,429$ & $1,941,355$ & 3.913 & $* * *$ \\
\hline Observations & 192 & 146 & 67 & 405 & & \\
\hline
\end{tabular}




\subsection{Local perceptions of saving}

Exploring the local perception of savings - semippu in Tamil, which means how people protect themselves from daily hazards and plan for the future - brings to light three types of informal savings, which are used alongside saving on a bank account: gold, ROSCAs (chit funds), and lending to others. Usage of those tools sometimes goes beyond earmarking them as saving and fulfils various objectives. Nonetheless, those tools were considered as forms of saving by the local population, and assumed a key role in the management of household cash flows. They can thus be qualified as multipurpose saving tools, echoing the idea of multipurpose money suggested by Polanyi (1977). This section discusses the roles of the three informal saving practices in both the households' short-term and long-term financial management and how they are embedded in their social realities.

Gold is the primary form of keeping assets and most often takes the form of jewels. It is first and foremost an ostentatious item and an outward sign of social status. At the time of specific rituals, in particular the ceremony of the first birthday, puberty, marriages and funerals, gold exchanges between families or within families fulfil an important symbolic function. Most importantly, gold is a chief component of matrimonial alliances and dowries. Social norms prescribe various ways of gold exchanges as part of the wedding ceremonial act, with important variations between and within castes. Usually the bride receives jewellery from the groom to wear during the ceremonial act, and she receives the dowry from her own family that she takes to her husband's house. The quantity of the dowry is often being determined socially, mostly with reference to caste and class, and through negotiation. Families sometimes start accumulating gold years before a daughter's marriage. For families of low social status, the amount of gold offered as dowry, plus additional items such as consumer goods or motorbikes, may decide about whether the marriage is approved by the groom's family. In particular among 
Dalits, aspirations for upward mobility translate into increasing amounts of dowry (and the practice of dowry in itself is a rather recent phenomenon). Gold accumulation can thus be viewed as a form of long-term saving, albeit unequally across class and castes.

Gifts in gold are distributed to a wide range of relations: its relative value, in terms of weight and relative purity, 'reflects both the giver's economic status and the closeness of their relationship' (Fernandez et al., 2011: 102). Notwithstanding its role in cementing (or distending) relationships, gold is a true marker of local hierarchy: gold ownership, which is made public at the time of rituals, is one indicator of households' social position.

Additionally, gold has a purely economic and financial function. First, it serves as a buffer, with jewellery very frequently pledged and sometimes sold in case of problems. Some jewels, in particular the marriage necklace worn by women called thaali, are considered inalienable goods and will be pledged only in case of great difficulty, but many others are 'almost cash' (Osella and Osella, 2000: 134). Gold can be converted almost immediately into a cash value pawnshops can be found at every street corner - and can be re-converted equally promptly. Gold finances urgent expenses: a child ring may be pledged to pay for school allowances, an earring for hospital fees, a pendant for repaying past debt, etc. When women are asked how they cope with emergencies, their first reply is often: 'The things I wear on my ears and hands'. Bouman (1989: 71) describes gold in India as 'everyone's piggybank'. Gold also circulates within close social circles: a woman in need may borrow temporarily the jewel of a trusted friend or relative. Within various circles, the velocity of gold circulation is astonishing. Furthermore, gold pledge serves midterm investments (Joseph, forthcoming). For a long time and till today farmers have been used to putting aside their jewels early in the crop year and getting them back at harvest time. Today pawnshops target a broad range of customers but historically they were specialized on the financing of agriculture. Many petty entrepreneurs often use family jewels to manage their cash flows. Banks and financial companies have 
perfectly well understood the importance of gold in households' financial strategies and all of them offer loans against gold. In our sample, more than one third of gold (37.5\%) on average was pledged (mostly with pawnshops) at the time of the survey. Pawn broking is one of the most convenient borrowing options (Guérin et al., 2012): it combines simplicity (procedures are very simple), anonymity (transactions take place outside the village) and freedom of use. Further, although often viewed as expensive, pawn broking remains relatively cheap compared to alternative options, with interest varying between $2 \%$ and $3 \%$ monthly.

Last but not least, over the last two decades gold has been a very efficient means of speculation with a high rate of return (the price of gold has more than quadrupled between 2000 and 2010). Lack of safety due to theft or loss and risk of bad quality do not seem to be an issue. Overall, gold has the advantage of combining prestige, speculation and liquidity. One can thus easily understand why household are more inclined to save in gold than in cash or a bank-account. ROSCAs, which is an umbrella term for an informal savings club, are also widespread. In India they come under the names chit funds or seetu. Various types of ROSCAs exist, and we distinguished between three types. First, in auction ROSCAs (which make up $40 \%$ of the total number of ROSCAs identified in the survey), the prize goes to the highest bidder. Those ROSCAs can be used for emergency purposes, but also for accumulation: those who take it at the end usually get the full pot, while the first ones usually pay a high interest (when demand is high) and the amount is shared among the remaining participants. As a second type, one finds lottery ROSCAs (33\%), in which the winner is randomly chosen and is then not eligible anymore but continues to pay his/her share. Participation in these two dominant forms of ROSCAs typically varies by sex, which we also observe in our data: Men rather participate in auction ROSCAs than in lottery ROSCAs (2.5 times as often), while women are more likely to be part of lottery ROSCA instead of an auction one (1.6 times as often). The third category $(27 \%)$ includes implicit forced saving systems aiming a specific expense planned in advance. 
Members save regularly and all will get the fruits of their efforts at the end, most often jewels, a pilgrimage or sometimes vessels. This may allow a cheaper access to goods of services as they are bought in bulk. ROSCAs are a well-studied phenomenon worldwide. In the region surveyed, ROSCAs do not have the social and convivial dimension observed in other parts of the world. Except for pilgrims, members hardly meet and transactions are managed by one organizer.

A third main form of saving in the region, as we have been told very frequently, is private lending to others. Price and repayment modalities vary greatly and depend upon three main factors: how close the two parties are, how urgent the borrower's request is and what degree of liquidity the lender is looking for. If the lender wants to keep money liquid, the loan should be reimbursed once she/he is in need. In other cases, lending is perceived as a form of mid or long term investment: the lender demands only regular interest payments, whilst retaining the rights over the principal. The latter will be paid after a few month or years. It is important to note that people who give private loans may well simultaneously borrow money (or have outstanding debt). Borrowing from various sources is an integral part of everyone's short-term cash flow management. Lending in turn, as mentioned before, is in many instances explicitly considered a form of saving, as observed in other contexts (Morvant-Roux 2013).

Another important feature of private lending is that it obeys to social considerations: financial transactions cement pre-existing social relations. Some are clearly based on hierarchy, that is on caste or social class. For instance, a landowner lending money to his labourers expects loyalty, deference and a number of free services. Any new loan strengthens labourers' dependency. At the same time the employer/lender plays a crucial role of protection which explains that all things being equal, debtors have a vested interest in staying in debt. Other financial transactions are rather based on solidarity and reciprocity ('I lend you today, you'll lend me tomorrow'). Here, lending might be a way to express one's feeling of loyalty to the 
community (with a strong prevalence of lending within the caste, as we shall see in Section 4.3). It might also be a way to strengthen a relation of closeness with the borrower: between people of equal status, lending (or, conversely, borrowing) expresses a feeling of trust. This personalization of debt relationships can thus affirm solidarity but also reinforce subordination. Sometimes extreme flexibility or debt cancelation conceals relationships of subjugation and exploitation. In any case, people perceive and manage their finances within those social relationships.

\subsection{The social regulation of savings}

By social regulation of savings, we mean that social institutions such as social class and caste shape the nature and the propensity to save. While banks play only a minor role for lending (Guérin, D’Espallier and Venkatasubramanian, 2013), the financial inclusion policies boosted the take-up of saving bank accounts in recent years (RBI, 2013). In addition, at the time of the survey, there were three microcredit providers in the area. None of them offered a saving account, but all were linked to local banks through the Self-Help-Group linkage program. The abovementioned phenomenon of low usage despite high take-up is mirrored in our study. Almost nine out of ten households possess a bank account, while the overall rate of dormant accounts is $25 \%$ (Figure 1$){ }^{6}$

The most common explanation given by bankers and social workers is that rural dwellers would be 'backward' or that they 'do not want to develop', as we have been told frequently. This

\footnotetext{
${ }^{6}$ Bank accounts can be used in several ways, for instance for small but frequent everyday transactions, or for larger but only occasional transactions (typical for savings accumulation). We define a bank account to be dormant or inactive simply if it shows zero balance. Although this may include households that are actively using their bank accounts but just 'happen' to have no money on their account at the time of the survey, we believe this is unlikely. On the other hand, households keeping a small amount on the bank while not performing any transactions, would be, rather inappropriately, counted towards active bank account users. This further mitigates the risk of overestimating the rate of dormant accounts.
} 
attitude explains why rural clients, especially Dalits, prefer to avoid being confronted with bank employees and generally have a lack of confidence when dealing with them. Dalit women in particular told us about their experiences of being patronized and despised by bankers, who would treat them as 'dogs' or 'goats'. However, while indeed Dalits have access to bank accounts to a lesser extent than middle and upper castes, Figure 1 shows that the discrepancy between access and active usage is common for all castes, varying between $22 \%$ (upper castes) to $27 \%$ (middle caste).

Figure 1: The share of active and dormant bank accounts

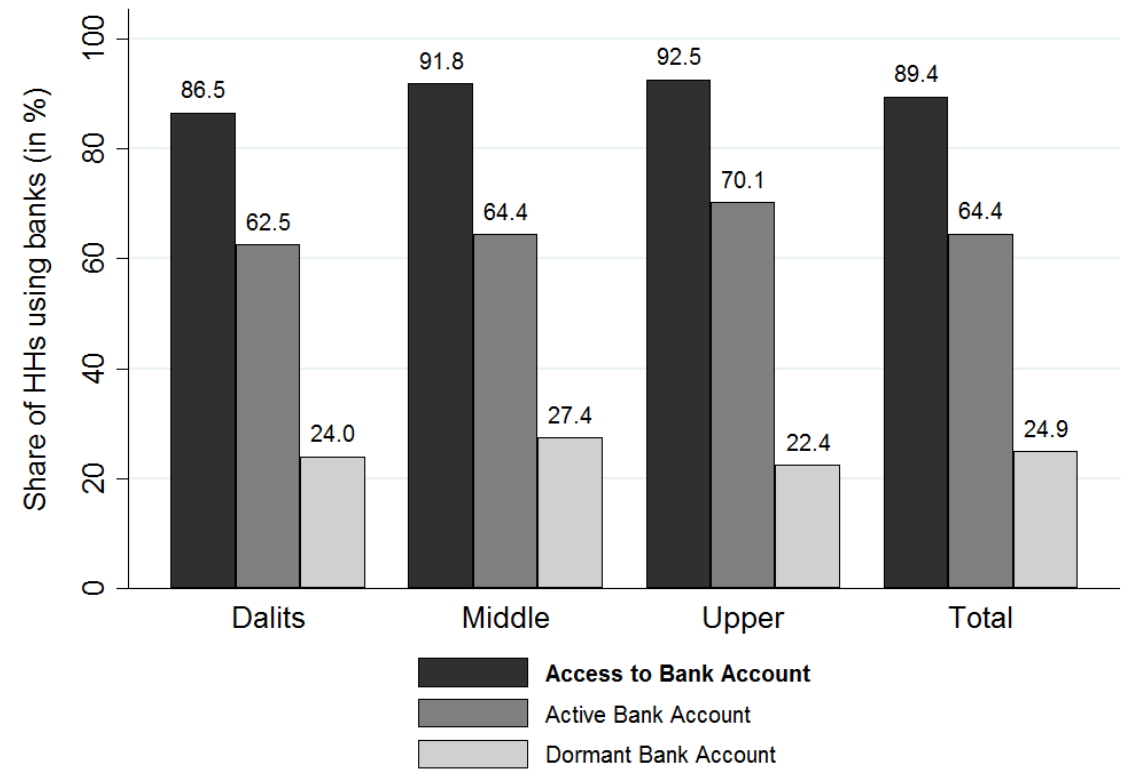

Source: The authors, RUME survey 2010.

Figure 2 displays the share of households in each caste that uses a particular type of saving. Gold is by far the primary form. In fact, every single surveyed household reported some possession of gold, underlining its ubiquitous importance in the sample area. $59 \%$ of the households are members of at least one ROSCA, and $61 \%$ have issued outstanding private 
loans at the time of the survey. Those shares are distributed rather similar between castes, albeit private lending is somewhat more common in the highest caste $(67 \%)$ compared to Dalits $(59 \%)$

Figure 2: The usage rate of informal saving types

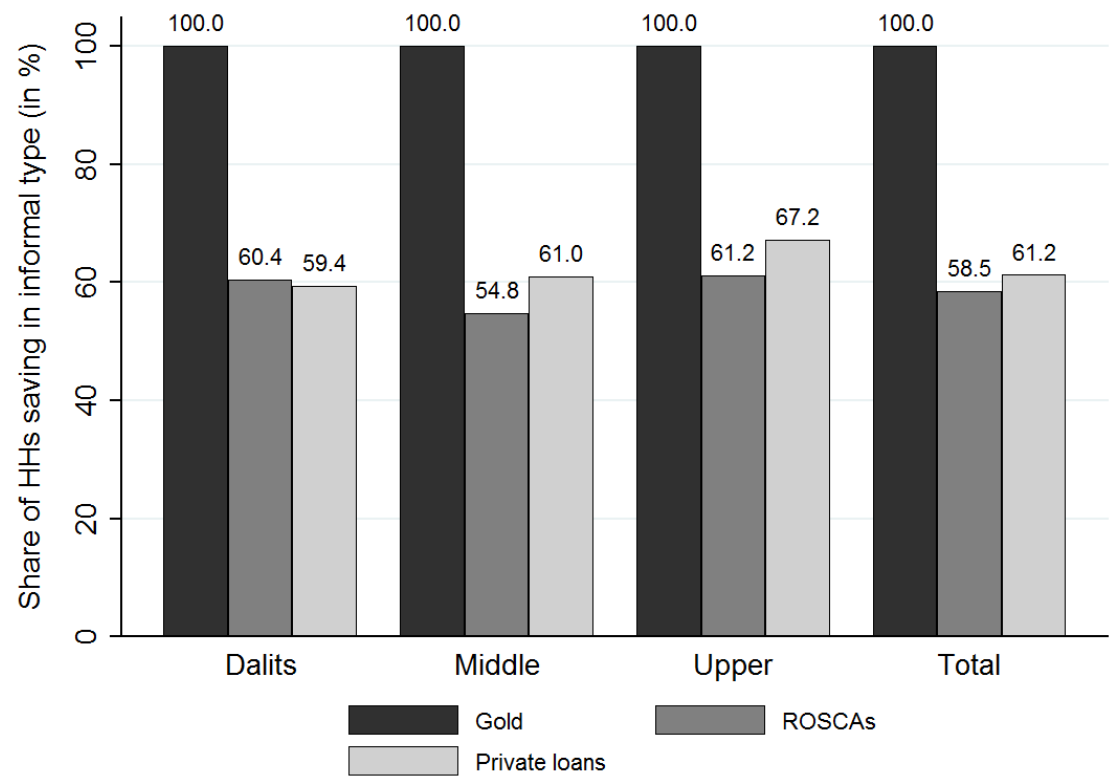

Source: The authors, RUME survey 2010.

Figure 3 depicts the average balances reported per caste at the time of the survey, where the amounts are conditional, that is they only include those households that actually use a specific saving type. The numbers confirm the picture drawn before: Gold possessions constitute by far the highest value (80,356 INR), followed by money circulating in ROSCAs (30,065 INR), and private loans $(9,853$ INR), whereas bank accounts play the smallest role with an average balance of 8,473 INR. It is striking that for every caste, bank account balances are exceeded by any type of informal saving vehicle. Thus, even among those who use their account, informal savings turn out to be much more relevant than formal savings. 


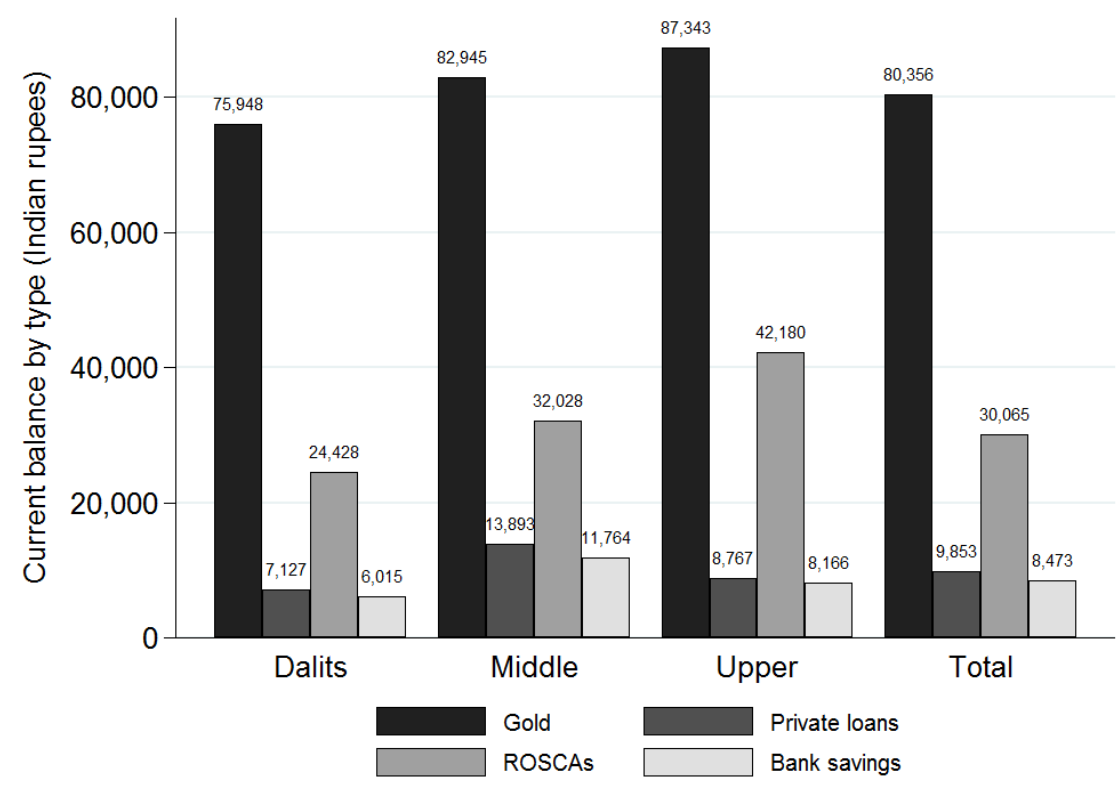

Source: The authors, RUME survey 2010. Notes: 45 INR $=1$ USD

In line with the multiple roles of gold - simultaneously serving as quasi-liquid asset, symbol of status, future investment and means to comply with social obligations - the overwhelming part of value surplus owned by the household is kept in gold. As argued above, the frontier between precautionary and investment saving is especially opaque for gold.

While the different purposes of holding gold may be weighted differently by households and cannot be disentangled by the data, gold may have a varying relative importance for households with different social statuses. Therefore, we estimated the determinants of the household's propensity to save in gold, as compared to other forms of saving. We only consider owned and disposable gold in our analysis, i.e. pledged gold is discarded. While in theory, pledged gold is still owned by the household who pledges it, in practice there is a real and perceived risk that 
it will not be restituted. This is particularly true for lower castes and may thus influence the reporting behaviour for the amount of pledged gold. ${ }^{7}$

We define propensity as the relative preference to store surplus in a given way compared to other ways. For a given savings type $i$ (where $i$ represents Gold, ROSCAs, Lending to Others, or Bank Savings), it is calculated as the amount of savings $x_{i}$ divided by the sum of total savings plus the value of all physical assets, $A$ :

$$
\text { Propensity }_{i}=\frac{x_{i}}{\sum_{j} x_{j}+A}
$$

Table 2 shows the estimated determinants of the propensity to save in each of the informal ways. Following the SUR methodology, the error terms across the equations are allowed to follow a joint distribution with nonzero covariance, reflecting that the different ways a household uses to save are interrelated. The set of independent variables is the same in all equations, such that the SUR estimators are equivalent to the Ordinary Least Squares estimators (Greene, 2003: 343).

Due to the particular role that gold plays in dowries, the accumulation of gold for anticipated marriages can be expected to depend on the gender of the adolescents within a household. Therefore, we control for household member composition in the regression specifications. This prevents a potential bias in the results caused by households either recently accumulating gold prior to an imminent dowry (in case of the prospective wife's family), or by households recently having received a dowry (in case of the husband's family).

\footnotetext{
${ }^{7}$ To check the results for robustness, however, all analyses were also run with pledged gold added to the amount of gold owned. This did not affect the point estimates, neither in magnitude nor in significance. Results are available from the authors upon request.
} 
The first column reveals that Dalits, other things constant, have a significantly $(<0.1 \%)$ higher propensity of investing their surplus in gold. This holds next to the finding that farmers keep a significantly lower share of their assets in gold, which is mostly because farmers rather invest into assets such as farm inputs. Interestingly, the Dalit coefficient is not significantly different from zero for ROSCAs, neither for private loans nor for bank savings. ${ }^{8}$ In other words, those forms of saving are equally important across castes, while gold exhibits a particularly high merit for lower castes.

\footnotetext{
${ }^{8}$ For dependent variables 'bank savings', 'ROSCA contributions', and 'private loans' we excluded any zeros. Thus, households reporting no utilization of those saving types did not enter the analyses. We also ran Probit regressions with a dummy variable indicating whether the respective saving tool is used or not, but do not report them here since they had little explanatory power.
} 
Table 2: What determines the propensity to save?

\begin{tabular}{|c|c|c|c|c|}
\hline \multirow{3}{*}{ Propensity to save in... } & (1) & (2) & (3) & \multirow{2}{*}{$\begin{array}{l}(4) \\
\text { Formal saving }\end{array}$} \\
\hline & \multicolumn{3}{|c|}{ Informal saving } & \\
\hline & Gold & ROSCA & Lending & Bank \\
\hline \multirow[t]{2}{*}{ Dalits } & $0.515 * * *$ & 0.0927 & -0.0101 & 0.0677 \\
\hline & $(3.92)$ & $(0.40)$ & $(-0.05)$ & $(0.30)$ \\
\hline Farmer & ref. & ref. & ref. & ref. \\
\hline \multirow[t]{2}{*}{ Casual labour } & $1.188 * * *$ & $1.032 * * *$ & $1.103 * * *$ & $0.983 * *$ \\
\hline & $(6.79)$ & $(3.70)$ & $(4.45)$ & $(2.68)$ \\
\hline \multirow[t]{2}{*}{ Employed } & $0.912 * * *$ & $0.845^{* *}$ & $1.029 * * *$ & 0.583 \\
\hline & $(4.95)$ & $(2.95)$ & $(3.95)$ & $(1.66)$ \\
\hline \multirow[t]{2}{*}{ Self-employed } & $1.200 * * *$ & $1.177 * * *$ & $0.899 *$ & $0.850 *$ \\
\hline & $(5.75)$ & $(3.87)$ & $(2.58)$ & $(2.15)$ \\
\hline \multirow[t]{2}{*}{ Female Head of household } & 0.286 & 0.195 & $-0.790 *$ & -0.136 \\
\hline & $(1.09)$ & $(0.39)$ & $(-2.12)$ & $(-0.32)$ \\
\hline \multirow[t]{2}{*}{ Rainfed Village (Dummy) } & 0.160 & 0.295 & 0.234 & $1.176^{* * *}$ \\
\hline & $(1.31)$ & $(1.38)$ & $(1.27)$ & $(5.40)$ \\
\hline \multirow[t]{2}{*}{ Dependency Ratio } & -0.485 & 0.00208 & -0.474 & 0.533 \\
\hline & $(-1.25)$ & $(0.00)$ & $(-0.81)$ & $(0.77)$ \\
\hline No Education & ref. & ref. & ref. & ref. \\
\hline \multirow[t]{2}{*}{ Primary Educ. } & -0.151 & 0.510 & $-0.548^{*}$ & 0.0121 \\
\hline & $(-0.88)$ & $(1.95)$ & $(-2.31)$ & $(0.04)$ \\
\hline \multirow[t]{2}{*}{ At least Secondary Educ. } & -0.00138 & $0.706^{* *}$ & -0.197 & 0.263 \\
\hline & $(-0.01)$ & $(2.92)$ & $(-0.88)$ & $(1.01)$ \\
\hline \multirow[t]{2}{*}{ Head Age } & -0.0104 & 0.0169 & -0.0112 & -0.00578 \\
\hline & $(-1.37)$ & $(1.23)$ & $(-0.90)$ & $(-0.43)$ \\
\hline \multirow[t]{2}{*}{ Household Size } & 0.0405 & -0.184 & 0.00900 & -0.0369 \\
\hline & $(0.61)$ & $(-1.42)$ & $(0.09)$ & $(-0.35)$ \\
\hline \multirow[t]{2}{*}{ \# boys in household } & 0.0438 & 0.306 & 0.00236 & 0.0998 \\
\hline & $(0.55)$ & $(1.94)$ & $(0.02)$ & $(0.76)$ \\
\hline \multirow[t]{2}{*}{ \# unmarried girls age $14+$} & -0.0500 & 0.0837 & $-0.347 *$ & 0.182 \\
\hline & $(-0.50)$ & $(0.42)$ & $(-2.33)$ & $(1.17)$ \\
\hline \multirow[t]{2}{*}{ \# daughters-in-law in household } & -0.171 & 0.0256 & -0.339 & 0.163 \\
\hline & $(-0.99)$ & $(0.07)$ & $(-1.06)$ & $(0.48)$ \\
\hline Observations & 404 & 237 & 248 & 260 \\
\hline R-squared & 0.215 & 0.117 & 0.167 & 0.158 \\
\hline
\end{tabular}

Several explanations can be given. Gold, as we have seen, is especially attractive due to its versatility. But yet another advantage from the perspective of lower castes is that it can reduce their financial dependency on higher castes. Historically, debt in India has always been a powerful vehicle of caste hierarchy (Hardiman, 1996). The relative emancipation of Dalits in the surveyed region is closely associated with a reduction of Dalits' dependency in terms of labour but also in terms of debt (Guérin et al., 2014). Even if Dalits still depend heavily upon higher castes for debt, pawn broking is clearly considered a socially desirable alternative. 'It is 
a right', as we have been told a number of times. Besides, for Dalits, regularly buying and pawning gold is a rather new phenomenon. According to various testimonies both from Dalit households and pawnshops, it started two to three decades ago. Our own estimations confirm that in the three main towns of the region, the number of pawnbrokers (many of whom are also jewellers) has increased at least tenfold over the last decade. This rising interest for gold combines three interrelated factors: the massive shift to non-farm labour outside villages, the improvement of wages and the willingness to climb the social ladder. The latter means both the acquisition of assets, including ostentatious goods, and freedom from higher castes. Gold, thanks to its multiple functions, is a possible response to these expectations.

Conversely, Dalits are constrained in accumulating certain asset types. As mentioned in Section 4.1, this notably concerns land holdings, which are hardly traded across caste lines. In addition to this, lending out money to higher castes is socially unacceptable for many higher caste members. This barrier is investigated in detail in the following.

Table 3 shows estimates resulting from a Bivariate Probit model that indicates to whom loans are granted. The first binary dependent variable indicates whether a household has given at least one loan to a Dalit household, and the second one indicates whether at least one loan has been given to a non-Dalit household. Since it is not uncommon to have outstanding loans to several households at the same time, lending out to Dalits and lending out to higher castes are not mutually exclusive. The Bivariate Probit assumes that the probability of positive outcomes of the two indicator variables is jointly normal with nonzero covariance, which is denoted by $\rho$. That is, whether a household grants a loan to a non-Dalit household might affect the likelihood that the same household will also grant a loan to a Dalit household, and vice versa. The coefficients of both equations and the correlation of the errors are jointly established by maximizing the likelihood function. 
In the first column of Table 3 it can be seen that Dalits are much more likely than other castes to lend money to other Dalits, while, as displayed in the second column, it is very uncommon that a Dalit issues a loan to someone belonging to a higher caste. Both coefficients are highly significant $(\mathrm{p}<0.1 \%)$. Another interesting result comes from the interaction terms in the first two rows. They capture how land ownership, given the lending caste, affects the likelihood of lending to a member of a certain caste. The first column shows that within the group of Dalits, land owners are significantly $(\mathrm{p}<0.1 \%)$ more likely to lend out money to their caste fellows than are landless families. Likewise, as shown in the second column, middle and upper caste families with land holdings are more likely to lend money to other members of those castes (even though the p-value remains just above the 5\% significance threshold). Those variables turn out to be more important than other explanatory household characteristics. In line with these results, we estimated a negative correlation (-0.208) of the errors terms, which says that after controlling for all independent variables, lending to other households is still separated between castes.

To summarize, first of all, caste is the main stratum when it comes to social and financial transactions among households. However, within that stratum, differences in land ownership play a significant role, too. 
Table 3: Bivariate Probit regressions. Who lends money to whom?

\begin{tabular}{lll}
\hline & $(1)$ & $(2)$ \\
& Lending to Dalits & Lending to middle or upper caste \\
\hline Dalits & $0.902^{* * *}$ & $-1.229 * * *$ \\
& $(3.90)$ & $(-5.04)$ \\
Int $\left(\right.$ Land Owned $\times$ Dalits) ${ }^{\mathrm{a}}$ & $0.813^{* * *}$ & -0.430 \\
& $(4.01)$ & $(-1.33)$ \\
Int $($ Land Owned $\times$ Middle/Upper Caste) $)$ & -0.205 & 0.354 \\
& $(-0.85)$ & $(1.84)$ \\
Farmer & $(1.01)$ & ref. \\
Casual labour & $0.573^{*}$ & -0.417 \\
& $(2.10)$ & $(-1.80)$ \\
Employed & -0.0633 & -0.438 \\
& $(-0.20)$ & $(-1.82)$ \\
Self-employed & -0.205 & -0.332 \\
& $(-0.85)$ & $(-1.30)$ \\
No Education & ref. & ref. \\
Primary Education & 0.0833 & 0.324 \\
& $(0.42)$ & $(1.55)$ \\
At least Secondary Education & -0.00829 & 0.132 \\
& $(-0.04)$ & $(0.73)$ \\
Control variables included ${ }^{\mathrm{b}}$ & YES & YES \\
\hline Observations & 404 & \\
Correlation of errors $(\rho)$ & -0.208 & \\
$\chi^{2}$ test of independence & $3.089(\mathrm{df}=1)$ & \\
Wald $\chi^{2}$ model fit & $226.70 * * *(\mathrm{df}=26)$ & \\
\hline
\end{tabular}

Source: The authors, RUME survey 2010. Notes: *,** and *** denote significance at $5 \%, 1 \%$ and $0.1 \%$ levels. $t$-statistics given in parentheses. 'df' is degrees of freedom.

${ }^{\text {a }} \operatorname{Int}($.) denotes interaction terms.

${ }^{\mathrm{b}}$ Control variables included but not reported: Female head of household, Rainfed village, dependency ratio, Age of household head, household size, constant parameter. Full table available from the authors upon request.

\subsection{Implications for 'financial inclusion'}

The previous analyses convey that saving for the rural poor is a complex issue. Many different forms of putting money aside coexist, which differ in liquidity, their degree of social interaction, profitability, and their constraints. It is an explicit aim of Indian policymakers to financially include the majority of the population, which particularly targets poor and rural households. It can be questioned however, whether there is sufficient demand for this kind of financial integration. For instance, the active usage of bank accounts can be subject to network effects: if most financial transactions a household is engaged in, such as wage payments, chit contributions as well as bigger investments, are handled through cash, then using a bank account may not represent any benefit (Salignac et al., 2016). 
A key assumption of the SUR model, which we applied to the propensity to save in each of the different ways in the previous section (see Table 2), is that the set of linear equations is stochastically related via their error terms. It therefore allows to estimate the residual correlations of the different saving vehicles. The case of successful financial inclusion would imply a shift from informal savings to bank savings, and thus a negative correlation between the two.

Table 4 exhibits the estimated correlation matrix of the SUR model for saving vehicles as applied in the previous section. Bank savings display a modest but significantly positive correlation with gold (.15) and ROSCA (.13) savings, and a correlation not significantly different from zero with private lending (.06). We thus do not find any evidence for substitution effects between informal and formal saving practices, even though no causal effects can be concluded from the correlations due to the cross-sectional nature of the data. On the other hand, informal savings expose a stronger correlation with each other than with bank savings. In particular, the partial correlation between gold and ROSCA savings is high (.42). Taken together, the correlations among the savings vehicles indicate that social capital - defined here as the social connections people have - is the driver of savings: households owning larger amounts of gold are also more welcome to participate in ROSCAs, or more inclined to lend out money to other households. At the same time, the correlations give little support for successful financial inclusion efforts.

Table 4: Error Correlation Matrix from SUR model

\begin{tabular}{llcc}
\hline & Gold & Bank & ROSCA \\
\hline Bank & $0.1534^{* *}$ & & \\
ROSCA & $0.4229^{* * *}$ & $0.1311^{* *}$ & $0.1089^{*}$ \\
Lending & $0.1634^{* *}$ & 0.0583 & levels
\end{tabular}




\section{Conclusion and discussion}

Comparing informal and formal saving practices of rural households in Southeast India, we find that even though take-up of bank accounts is wide-spread (89\% of sample households), the rate of dormant accounts is still substantial (25\%), and average amounts on the accounts are very low. Instead, informal savings are still dominant, where especially gold, fulfilling several roles regarding social relations as well as economic activities, meets a much higher demand as device to store value than does keeping money on a bank account.

The preference for gold is even more pronounced for lower caste members, the Dalits, who make relatively more use of gold to facilitate their cash flow management. Middle and upper caste households, while strongly relying on gold too, have also other means to accumulate their economic surplus. In particular, they are more likely to possess land, and furthermore their plots are larger on average and of higher value. This also manifests their political dominance, which is still attached to land holdings. Giving private loans to neighbours, kin, labourers or other socially related people is common and viewed as another form of saving. Those loan relationships remain largely within caste boundaries and cement pre-existing relationships. That goes hand in hand with our finding that landowners are more likely to give private loans than are landless households.

Further, we do not find any evidence for substitution effects between informal saving and bank saving, whereas we find strong positive associations among informal saving practices, affirming that social capital is a main driver of savings accumulation.

Providing the excluded part of the population with banking services is still high on the agenda of Indian policymakers. In 2014, and in continuation with earlier initiatives started in 2005, a large scale 'financial inclusion' program was launched (Government of India, 2014). Specifically, the program envisages a low-barrier and safe way to save, in order to establish 
non-cash money in everyday financial transactions, facilitate the provision of white label ATMs in rural areas, facilitate access to credit, and enable direct payment of social transfers by the government to target households. Immense expectations had been fuelled previously, announcing that the programme would eradicate 'financial untouchability', and even mark the 'beginning of freedom from poverty' (The Hindu Business Line, 2014). While indeed social transfers are now increasingly being disbursed directly through bank transfers (Morvant-Roux and Fouillet, 2015), our study suggests that a top-down approach to mobilise savings by simply providing low-cost access to bank accounts may not give the expected results.

From a policy perspective, approaching saving from a social, cultural and political economic perspective yields two insights. First, ignoring how people perceive and manage their savings is likely to result in a poor outcome in terms of behavioural change. Without any other structural changes, especially in terms of social protection, it is in the best interest of local populations to remain integrated into a wide range of relationships. The poor results of active 'financial inclusion' policies, based on an ethnocentric classical economic framework, are easily understood in light of our study. Second, focusing on bank savings (as do policymakers and a number of researchers) and on precautionary savings (as do many researchers) ignores another fundamental question: the access to asset accumulation. The capability to accumulate is, of course, facilitated by a better management of daily risks and hazards. But the capability to accumulate is also strongly influenced by structural factors, whether it is tax systems, inheritance rules and jurisdictions, or (formal or informal) restrictions in the exercise of specific jobs or the acquisition of specific assets. In the context of our study, prohibitions related to Dalits' access to land are undoubtedly a major barrier in accumulation patterns. 


\section{List of references}

Ashraf, N., Karlan, D. and Yin, W. (2010) 'Female empowerment: Impact of a commitment savings product in the Philippines', World Development 38(3), 333-44.

Atkinson, J.; Janvry, A; de, McIntosh, C. and Sadoulet, E. (2013) 'Prompting microfinance borrowers to save: A field experiment from Guatemala', Economic Development and Cultural Change 62(1), 21-64.

Banerjee, A. V. and Duflo, E. (2011) Poor Economics: A Radical Rethinking of the Way to Fight Global Poverty. New York: PublicAffairs.

Bouman, F. J. A. (1989) Small, Short and Unsecured - Informal Rural Finance in India. Oxford: Oxford University Press.

Cnaan, R. A., Moodithaya, M. S. and Handy, F. (2012) 'Financial Inclusion: Lessons from Rural South India', Journal of Social Policy 41(01): 183-205.

Collins, D.; Morduch, J.; Rutherford, S. and Ruthven, O. (2009) Portfolios of the Poor: How the World's Poor Live on \$2 a Day. Princeton: Princeton University Press.

Deaton, A. (1990) 'Saving in Developing Countries: Theory and Review', in S. Fischer and D. de Tray (eds), Proceedings of the World Bank Annual Conference on Development Economics 1989. Washington, DC: World Bank.

Demirgüç-Kunt, A.; Klapper, L.; Singer, D. and Van Oudheusden, P. (2015) The Global Findex Database 2014: Measuring Financial Inclusion Around the World. Policy Research Working Paper no. WPS 7255. Washington, DC: World Bank Group.

Douglas, M. and Isherwood, B. (1980) The Worlds of Goods. Harmondsworth: Penguin Books.

Dupas, P. and Robinson, J. (2013) 'Savings Constraints and Microenterprise Development: Evidence from a Field Experiment in Kenya', American Economic Journal: Applied Economics 5(1), 163-92. 
Dupas, P.; Green, S.; Keats, A. and Robinson, J. (2012) Challenges in Banking the Rural Poor: Evidence from Kenya's Western Province. Working Paper No. 17851. Cambridge, MA: National Bureau of Economic Research.

Fernandez, K. V., Veer, E. and Lastovicka, J. L. (2011) 'The Golden Ties That Bind: Boundary Crossing in Diasporic Hindu Wedding Ritual', Consumption Markets and Culture 14(3), $245-65$.

Government of India. (2014) A National Mission on Financial Inclusion. New-Delhi. Retrieved from http://financialservices.gov.in/banking/PMJDY\%20BROCHURE\%20Eng.pdf (accessed April 05, 2016)

Greene, W. H. (2003) Econometric Analysis. 5th ed. Upper Saddle River, NJ: Prentice Hall.

Guérin, I., D’Espallier, B. and Venkatasubramanian, G. (2013) 'Debt in Rural South India: Fragmentation, Social Regulation and Discrimination', Journal of Development Studies 49(9), 1155-71.

Guérin, I., Michiels, S. and Venkatasubramanian, G. (2014) 'Labour in contemporary South India', in J. Heyer and B. Harriss-White (eds), Capitalism in Development. London: Routledge.

Guérin, I., Morvant-Roux, S. and Servet, J.-M. (2011) 'Understanding the diversity and complexity of demand for microfinance services: lessons from informal finance', in B. Armendariz and M. Labie (eds), Handbook of Microfinance. London/Singapore: World Scientific Publishing.

Guérin, I., Morvant-Roux, S. and Villarreal, M. (eds) (2013) 'Conclusion', in Microfinance, Debt and Over-indebtedness. London: Routledge.

Guérin, I.; Roesch, M.; Venkatasubramanian, G. and D’Espallier, B. (2012) ‘Credit from whom and for what? Diversity of borrowing sources and uses in rural South-India', Journal of International Development 24, S122-37. 
Guyer, J. (1997) 'Endowments and assets: the anthropology of wealth and the economics of intrahousehold allocation', in L. Haddad, J. Hoddinott, and H. Alderman (eds) Intrahousehold Resource Allocation in Developing Countries: Methods, Models, and Policy. Baltimore, MD: Johns Hopkins University Press.

Hardiman, D. (1996) Feeding the Baniya. Peasants and usurers in Western India. Oxford: Oxford University Press.

Iversen, V.; Kalwij, A.; Verschoor, A. and Dubey, A. (2014) 'Caste Dominance and Economic Performance in Rural India', Economic Development and Cultural Change 62(3), 42357.

Joseph, N. (forthcoming) “"And our ears have been bare since then” Gold ownership, gender, and work vulnerability in a South Indian silk-reeling hub', in M. G. Fernandez and O. Ruthann (eds), Women's Access to Land, Labour and Livelihoods in 21st Century India. London: Palgrave.

Karlan, D., Ratan, A. and Zinman, J. (2014) 'Savings by and for the Poor: A Research Review and Agenda', Review of Income and Wealth 60(1), 36-78.

Labie, M., Laureti, C. and Szafarz, A. (2015) Discipline and Flexibility: A Behavioral Perspective on Product Design in Microfinance. Working Paper No. 15-020. Bruxelles: Université Libre de Bruxelles.

Levien, M. (2015) 'Social Capital as Obstacle to Development: Brokering Land, Norms, and Trust in Rural India', World Development 74, 77-92.

Morduch, J. and Sharma, M. (2002) 'Strengthening public safety nets from the bottom up', Development Policy Review 20, 569-88.

Morvant-Roux, S. (2013) 'Microfinance and over-indebtedness in rural Mexico’, in I. Guérin, M. Villarreal, and S. Morvant-Roux (eds), Microfinance, debt and over-indebtedness. London: Routledge. 
Morvant-Roux, S., and Fouillet, C. (2015) 'Public Policies, Financial Inclusion and Inequalities: A Review of Recent Trends in India and Mexico', Paper presented at the Conference on Inequality in the 21st Century, London, UK, July 2-4.

Morvant-Roux, S.; Guérin, I.; Roesch, M. and Moisseron, J.-Y. (2014) 'Adding value to randomization with qualitative analysis: the case of microcredit in rural Morocco', World Development 56, 302-12.

Osella, F. and Osella, C. (2000) Social Mobility in Kerala: Modernity and Identity in Conflict. London; Sterling, VA: Pluto Press.

Platteau, J.-P. (2000) Institutions, Social Norms and Economic Development. Amsterdam: Harwood Academic Publishers.

Polanyi, K. (1977) The livelihood of man. New York/London: Academic Press.

Rao, V. and Woolcock, M. (2003) 'Integrating Qualitative and Quantitative Approaches in Program Evaluation', in F. J. Bourguignon and L. Pereira da Silva (eds), The Impact of Economic Policies on Poverty and Income Distribution: Evaluation Techniques and Tools. Washington, DC: World Bank; New York: Oxford University Press.

Reserve Bank of India (RBI) (2013) 'Financial Inclusion: an Assessment'. New-Delhi. Available at: http://rbidocs.rbi.org.in/rdocs/Speeches/PDFs/MFI101213FS.pdf (accessed March 23, 2015).

Rosenzweig, M. R. (2001) 'Savings behaviour in low-income countries', Oxford Review of Economic Policy 17(1), 40-54.

Rutherford, S. (2001) The Poor and Their Money. Oxford: Oxford University Press.

Salignac, F., Muir, K. and Wong, J. (2016) ‘Are you really Financially Excluded if you Choose not to be Included? Insights from Social Exclusion, Resilience and Ecological Systems', Journal of Social Policy 45(02): 269-86. 
Servet, J.-M. (ed.) (1995) Épargne et Liens Sociaux. Études Comparées D'informalités Financières. Paris: Association d'Economie Financière.

Sherraden, M. (1991) Assets and the Poor: A New American Welfare Policy. Armonk, NY: M. E. Sharpe.

The Hindu Business Line (2014) 'End financial untouchability for freedom from poverty: PM', Published on 28 August, http://www.thehindubusinessline.com/banking/end-financialuntouchability-for-freedom-from-poverty-pm/article6360972.ece (accessed August 17, 2015)

Vogel, R. C. (1981) Savings Mobilization: The Forgotten Half of Rural Finance. Washington, DC: Economic Development Institute of the World Bank.

Vonderlack, R. M. and Schreiner, M. (2002) 'Women, microfinance, and savings: lessons and proposals', Development in Practice 12(5), 602-12.

Zellner, A. (1962) ‘An Efficient Method of Estimating Seemingly Unrelated Regressions and Tests for Aggregation Bias', Journal of the American Statistical Association 57(298): $348-68$.

Zellner, A. and Lee, T. H. (1965) 'Joint Estimation of Relationships Involving Discrete Random Variables', Econometrica 33(2): 382-94. 